\title{
REAL ESTATE DEVELOPER'S PRODUCT POSITIONING: AHP-UTILITY-BASED MODEL
}

\author{
Ting-Yi CHIANG* \\ Department of Architecture, National Taiwan University of Science and Technology, No.43, Sec. 4, Keelung Rd., \\ Da-an Dist., Taipei City 10607, Taiwan
}

Received 22 November 2018; accepted 04 March 2019

\begin{abstract}
Inappropriate land development decisions lead to wasted land resources; such bad decisions can negatively impact urban landscapes and the environment, which makes the decision of an appropriate residential environment difficult. Therefore, a suitable assessment model is required to resolve this complexity. The present study applied the fuzzy Delphi method, analytical hierarchy process, utility theory, and other research methods to construct an evaluation model for residential environment location. the study findings reveal that consumers are attracted by regional environmental conditions and architectural design. However, the study found that community welfare is neglected. This model can help decision makers to evaluate utility values and profitability, in order to select the most suitable environment. Therefore, related authorities should strengthen community welfare and neighborhood development. Furthermore, social resources should be integrated in order to deliver social welfare and services to the community, thus enabling people in the community to obtain the necessary resources and assistance.
\end{abstract}

Keywords: residential environment, decision, fuzzy Delphi method, analytical hierarchy process, utility theory.

\section{Introduction}

Human activity is increasing global pollution and causing many environmental problems. Green building is a trend that countries have already prioritized; additionally, countries are constantly and actively improving environmental management implementation (Altomonte, Schiavon, Kent, \& Brager, 2019; Paul \& Taylor, 2008; Retzlaff, 2008; Zhang, Platten, \& Shen, 2011). Practitioners of green building design primarily advocate low-carbon construction and maintenance to conserve energy and reduce environmental pollution (GhaffarianHoseini et al., 2013; Pohekar \& Ramachandran, 2004). Practitioners of green building design mainly promote low-carbon construction and maintenance to conserve energy and reduce environmental pollution (GhaffarianHoseini et al., 2013; Pohekar \& Ramachandran, 2004). Innovative green building designs are defined in this study as the achievements by improving or creating new things, methods, paths, and environment, with the approach of proposing ideas that differ from conventional thinking using the existing thinking pattern. Through innovative technologies and advanced materials, [the goals of] "energy-saving, waste-minimizing, and healthy" buildings are to be achieved. Hence, the extension of innovative green building practices will compensate for the inadequacies in the existing building designs with respect to economic effectiveness, practicality, durability, and comfort. This study focuses on green building design because Taiwan is facing a slowdown in population growth, an aging demographic structure, low birth rate, and other phenomena as well as a gradually increasing proportion of old buildings, economic instability, high housing prices, and other challenges. These problems prompt redefinition of residential decisions with regard to green design to help companies cope with the rapid social changes, severe competition, diminishing gross annual profits, and other problems. Through literature review, the present study identifies several environmental factors that affect people's living options, mainly the indoor spaces of buildings and residential environment location options. Although several studies have investigated green design, they are inadequate (Ali \& Al Nsairat, 2009; Lam, Chan, Poon, Chau, \& Chun, 2010; Liu, Hsueh, Wu, \& Chen, 2012). Using Taipei City's social housing as an example, the present study applied the fuzzy Delphi method, analytical hierarchy process, utility theory, and

*Corresponding author. E-mails: d10313014@mail.ntust.edu.tw; lv198012@gmail.com 
other research methods to construct an evaluation model for residential environment location. Risk-conscious preferences were included to verify the model's feasibility. The study presents an introduction and literature review, followed by a section outlining the methodology, research design, data collection, case study, and discussion. Based on the abovementioned discussion, three key points were explored by this paper:

- Fuzzy Delphi method (Ishikawa et al., 1993; Kuo \& Chen, 2008; Lee \& Seo, 2016) was applied to serve as the basis of screening decision factors to focus on the impacts of residential environment location on community service facilities, innovation green building design, building construction and other aspects.

- The characteristics of such decision theories as analytical hierarchy process and utility theory are used to develop a customer-oriented model of residential site selection evaluation. Although there have been several studies on this issue, their purposes differ and each has its own limitations (Chen, Cheng, Hsueh, \& Qu, 2017; Hsueh, 2012; Hsueh \& Yan, 2013), without having been practically applied to residential buildings. The present study uses the evaluation and comparison of the key factors, such as (1) various community service facilities, (2) innovative green building designs, and (3) construction as the evaluative tool for people in purchasing property and housing suppliers before launching their products.

- The people's livelihood discussion were followed through the application of evaluation model for residential environment location to verify the feasibility of the model.

\section{Literature review}

\subsection{Fuzzy Delphi method}

The disadvantages of Delphi's method include inconsistent expert opinions, high costs of enforcement, and modification of experts' individual opinions to reach a consistent overall view. The fuzzy set theory, proposed by Zadeh (1965), suggested that traditional scientific methods often ignored the uncertainty and ambiguities of human life; thus, he set out to use the fuzzy set theory and adopted the fuzzy logical concepts for the process. The fuzzy Delphi method (hereafter, the FDM) was proposed by Murray, Pipino, and Van Gigch (1985) to integrate the Delphi method and the fuzzy theory, aiming to improve the disadvantages of the Delphi method. Ishikawa et al. (1993) integrated expert opinions with fuzzy numbers on the basis of the concepts of cumulative frequency distribution and fuzzy integral. This process is the FDM, which has been widely used for index selection in many fields. FDM is better preferable to the Delphi method because it has the following advantages (Kuo \& Chen, 2008; Lee \& Seo, 2016; Zimmermann, 2010):

- Applying the fuzzy theory to clarify invertible fuzziness in expert interviews enables researchers to ob- tain better responses.

- A simple calculation process, handling multi-level, multi-attribute, and multi-solution decision problems.

- The achievement of greater economic effectiveness in time and costs required to conduct surveys.

- Reduction in the number of surveys required.

This study applied triangular membership functions and the fuzzy theory to solve a residential location problem.

\subsection{Analytical hierarchy process}

The analytical hierarchy process (hereafter, the AHP), a Multi-criteria decision-making, MCDM model proposed by Saaty (1990), is commonly applied in decision analysis in management and other fields. Related research has been conducted on the indoor-environment (Chiang \& Lai, 2002); sustainable energy planning (Pohekar \& Ramachandran, 2004); urban design (Bathrellos, Skilodimou, Chousianitis, Youssef, \& Pradhan, 2017) and a framework for design for sustainable future-proofing (Rehman \& Ryan, 2018). Evaluative factors for the event can be obtained through the use of the AHP questionnaire. Consistent inspection then can be used to obtain the balance and the relative weights of decision factors to solve multiattribute decision problems. AHP analysis can, however, only provide relative values. AHP combined with utility theory can yield anticipated utility values. A comparison between the pros and cons of the evaluative factors can provide decision makers with more valuable references.

\subsection{Utility theory}

Utility theory, proposed by Bernoulli in 1738, is used to express people's preferences and relative risk attitudes. A complex risk of uncertainty exists in decision-making; the advantage of utility theory is that it provides decision makers with a quantified mode of analysis to facilitate an enhancement of the objectivity of decisions (Luce, 1956). This mode of analysis functions as follows (Dozzi, AbouRizk, \& Schroeder, 1996; Hsueh, 2012):

- Specify the range of interest for each criterion, including the upper and lower limits $\left(y_{U}, y_{L}\right)$.

- Identify each criterion's neutral point of contribution, threshold $\left(y_{T}\right)$, and the most preferred point $\left(y_{M}\right)$.

- Develop utility functions using a straight line or an exponential function and solve for the constants of each equation.

- This study applied the risk neutrality utility function technique to establish each criterion's utility function.

- Define the cardinal utility scale by anchoring relative points.

Each criterion has an exclusive linear utility function $u_{i}\left(y_{i}\right)=A_{y i}+B$ and a fuzzy scale value between $\left(y_{H}, y_{L}\right)$, where $y_{m a}$ within the $y_{H}-y_{L}$ range is the most preferred point, $u_{i}\left(y_{m a}\right)=1$ and $y_{m i}$ is the worst point, $u_{i}\left(y_{m i}\right)=0$. 
First, $\mathrm{A}$ and $\mathrm{B}$ values in the $u_{i}\left(y_{i}\right)=A_{y i}+B$ were computed.

As $u_{i}\left(y_{m i}\right)=0 ; u_{i}\left(y_{m a}\right)=1$, we can obtain the following equations:

$$
\begin{aligned}
& u_{i}\left(y_{m i}\right)=A \cdot y_{m i}+B=0, B=-A_{y m i}, \\
& u_{i}\left(y_{m a}\right)=A \cdot y_{m a}+B=1, A=\frac{1}{\left(y_{m a}-y_{m i}\right)} .
\end{aligned}
$$

The expected utility value (EUV) equals to the sum of each criterion's relative ratings $u_{i}\left(y_{i}\right) \cdot$ weighting value $\left(W_{i}\right)$ and can be obtained using the following equation $\left(u_{i}\left(y_{i}\right)=u_{r i}\right)$ :

$$
\text { ExpectedUtilityValue }(E U V)=\sum_{i=1}^{n}\left(u_{r i} \cdot W_{i}\right) \text {. }
$$

After defining the fuzzy scale for $\left(y_{H}, y_{L}\right)$ and the values for $y_{m i}$ and $y_{m a}$, the constants A and B and the utility function for each criterion can be obtained using the above equation. Relevant utility theory-related research includes risk management (Han, D. Y. Kim, H. Kim, \& Jang, 2008); evaluating household energy conservation performance (Hsueh, 2012); interior environmental design (Chen et al., 2017) and determining how the insurance market affects investments in safety measures (Abrahamsen \& Asche, 2011). There have been a few study results on this research topic, but there is scant literature on location of the social housing residential environment. The present study used the AHP and the utility theory to explore residential environment location to assist government agencies or enterprises in improving customer satisfaction, which will be provide better results compared with the use of a single identification model. The present study combined four methodologies (i.e., fuzzy logic theory, FDM, AHP, and utility theory) and developed a multimethod competitive advantage assessment model for the system environment of construction supplier. The decision model used to choose residential environments in this study is based on scientific calculations and empirical case studies. This model can help decision makers to evaluate utility values and profitability, in order to select the most suitable environment. During the modeling process, the causal relationships in the overall industrial structure and the complex factors in the system environment were considered. Therefore, the proposed model can be applied under rapid changes in the market environment. The assessment model consisted of two parts: development and application. Model development confirmed three main input criteria to the fuzzy logic inference system (FLIS): $\mathrm{F}(\mathrm{X} 1), \mathrm{F}(\mathrm{X} 2)$, and $\mathrm{F}(\mathrm{X} 3)$, as shown in Figure 1.

\section{Data analysis methods}

\subsection{Questionnaire design}

After the collection of related documents and a consideration of in-depth expert interviews, the questionnaire was designed. Furthermore, the methods of qualitative and quantitative analysis were adopted. The purpose of indepth expert interviews was to afford respondents a better and in-depth understanding of the problem; in-depth

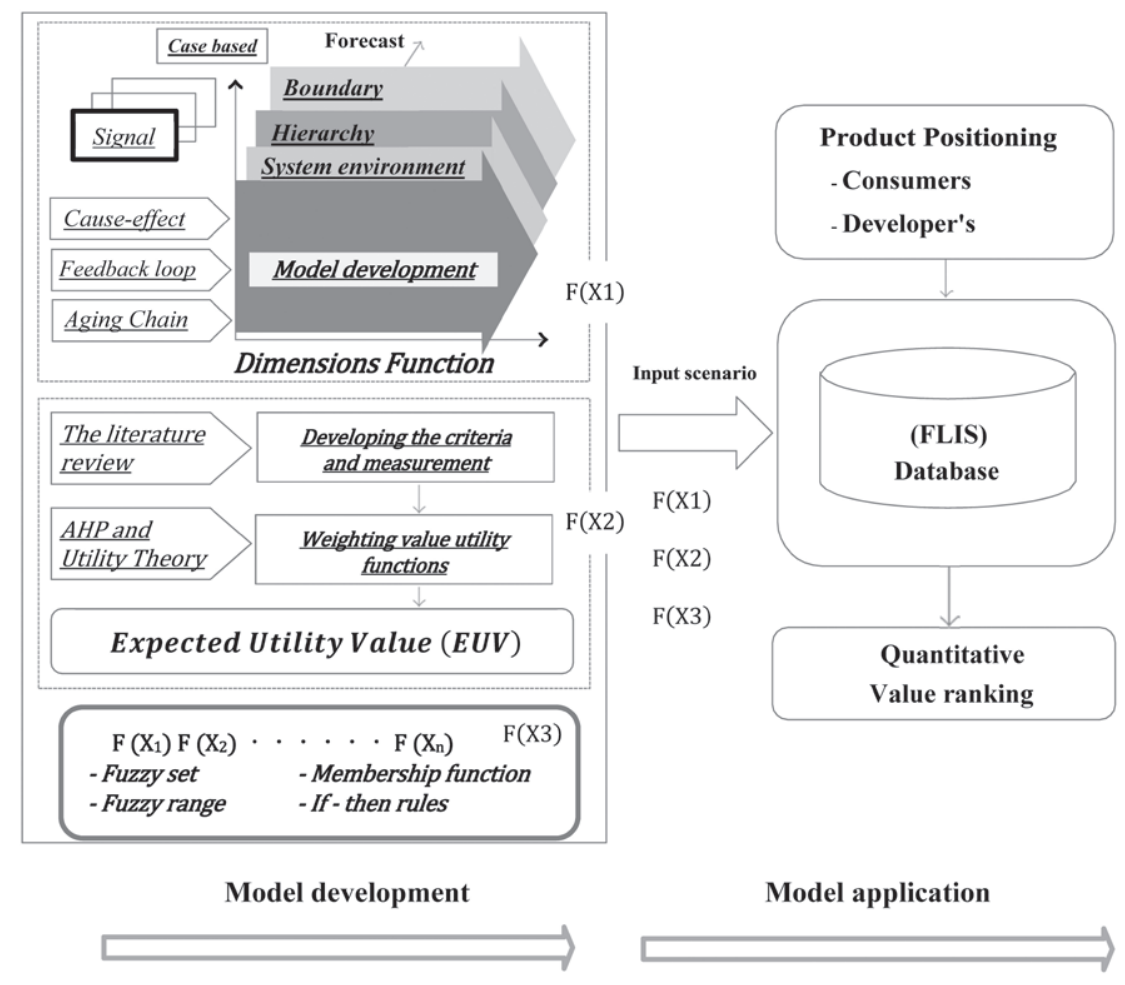

Figure 1. The proposed assessment model 
understanding has more value than broad understanding (H. J. Rubin \& I. S. Rubin, 2011). Respondents' personal observations may represent many people's experiences (Chiang, Perng, \& Liou, 2017; Weiss, 1994). There were 50 team members of FDM, namely, 15 specialists in the industry including architects and real estate appraisers, 15 executives with who had doctorates, 10 directors of government sectors, and 10 professors from prestigious universities. The policy of social residence was developed and amended by the Department of Urban Development. Regulations of the social residence management department are explicit and thus, it was easy to select appropriate experts and scholars. Five government directors and three professors were principal specialists in this field. They assisted in designing the questionnaire and advised the researcher so as to gain complete and effective data. The data was employed to create comfortable new life community service facilities $(\mathrm{F}(\mathrm{X} 1)=\mathrm{CS} 1-\mathrm{CS} 6)$, provide suitable residential environments for modern people who innovate green building design $(\mathrm{F}(\mathrm{X} 2)=\mathrm{IB} 1-\mathrm{IB} 5)$, and improve the quality of residential building construction $(\mathrm{F}(\mathrm{X} 3)=\mathrm{BC} 1-\mathrm{BC} 7)$. The data acquired was organized and compiled into questionnaires with 18 factors (Table 1). The survey questionnaire was divided into three parts. In Section A, through FDM, the experts and scholars classified and appraised the factors. In Section B, employing AHP ensured that qualitative judgment was quantified to provide precise comparisons and minimize or eliminate any unbalanced scale of judgments, imprecision and uncertainty among pair-wise comparisons (Borade, Kannan, \& Bansod, 2013). In Section C, AHP was combined with the theory of utility to gain the expected utility value.

\subsection{FDM factor screening}

FDM has been proved to utilize triangular fuzzy numbers to integrate the cognition of experts and scholars, and improve the limitations of the traditional Delphi method, which could only provide $50 \%$ of the information because of the repeated questionnaire survey. FDM has the advantage of semantically expressing the meaning more precisely (Kuo \& Chen, 2008; Lee \& Seo, 2016; Zimmermann, 2010). Therefore, the triangular membership function and fuzzy theory was applied to classify the appraisal factors to select residential locations. A total of 50 questionnaires were issued for the preliminary survey; 40 were completed and returned ( $80 \%$ response rate). FDM was applied for factor screening to remove factors with a low discrimination index and simplify the questionnaires further. The analysis results are shown in Table 2; there was an expert consensus threshold value $\left(G^{i}\right)$ of 6.71. Five factors, namely, community building (CS5), intelligent development (CS6), lessons learned (BC2), change of material type and specification during construction (BC5) and building production resume (BC7), had a value less than 6.71 and were thus removed; 13 factors remained.

Table 1. Factors for assessment criteria items

\begin{tabular}{|c|c|c|}
\hline Project aspect & Related factor & $\begin{array}{l}\text { Supporting documents } \\
\text { (References) }\end{array}$ \\
\hline \multirow{6}{*}{$\begin{array}{l}\text { Community service } \\
\text { facilities }\end{array}$} & 1. Cultural education facility (CS1) & {$[\mathrm{A}] ;[\mathrm{D}]$} \\
\hline & 2. Sport and leisure (CS2) & {$[\mathrm{D}] ;[\mathrm{H}]$} \\
\hline & 3. Living convenience facility (CS3) & {$[\mathrm{A}] ;[\mathrm{D}]$} \\
\hline & 4. Community welfare (CS4) & Proposed by experts \\
\hline & 5. Community building (CS5) & Proposed by experts \\
\hline & 6. Intelligent development (CS6) & Proposed by experts \\
\hline \multirow{5}{*}{$\begin{array}{l}\text { Innovation green } \\
\text { building design }\end{array}$} & 1. Safety design (IB1) & {$[\mathrm{B}] ;[\mathrm{E}] ;[\mathrm{L}] ;[\mathrm{M}]$} \\
\hline & 2. Health design (IB2) & {$[\mathrm{E}] ;[\mathrm{M}]$} \\
\hline & 3. Convenience design (IB3) & {$[\mathrm{B}] ;[\mathrm{E}] ;[\mathrm{L}] ;[\mathrm{M}]$} \\
\hline & 4. Comfort design (IB4) & {$[\mathrm{B}] ;[\mathrm{E}] ;[\mathrm{L}] ;[\mathrm{M}] ;[\mathrm{O}] ;[\mathrm{P}]$} \\
\hline & 5. Sustainability design (IB5) & {$[\mathrm{E}]$} \\
\hline \multirow{7}{*}{ Building construction } & 1. Foundation condition and terrain issue (BC1) & {$[\mathrm{K}]$} \\
\hline & 2. Lessons learned (BC2) & Proposed by experts \\
\hline & 3. Green construction materials (BC3) & {$[\mathrm{I}] ;[\mathrm{N}]$} \\
\hline & 4. Innovation technology (BC4) & {$[\mathrm{F}] ;[\mathrm{J}]$} \\
\hline & 5. Change of material type and specification during construction (BC5) & {$[\mathrm{K}]$} \\
\hline & 6. Schedule delay (BC6) & $[\mathrm{C}] ; \mathrm{G}]$ \\
\hline & 7. Building production resume (BC7) & Proposed by experts \\
\hline
\end{tabular}

Note: $[\mathrm{A}]=$ Hassan and Lee (2015); [B] = Afacan (2011); [C] = Chen, Liu, Li, and Lin (2011); [D] = EEWH-NC (2015); [E] = Kadir and Jamaludin (2013); [F] = Lam et al. (2010); [G] = Larsen, Shen, Lindhard, and Brunoe (2016); [H] = Murray and Howat (2002); [I] = Hwang and Ng (2013); [J] = Qi, Shen, Zeng, and Jorge (2010); [K] = Santoso and Soeng (2016); [L] = Demirbilek and Demirkan (2004); [M] = WHO (1961); [N] = Yang, Zou, and Wang (2016); [O] = Leaman and Bordass (2007); [P] = Zeeman, Wright, and Hellyer (2016). 
Table 2. Fuzzy Delphi method analysis result

\begin{tabular}{|c|c|c|c|c|c|c|c|}
\hline \multirow{2}{*}{ Factor } & \multicolumn{2}{|c|}{ Conservative value } & \multicolumn{2}{|c|}{ Optimistic value } & \multirow{2}{*}{$G^{i}$} \\
\cline { 2 - 7 } & $C_{L}^{i}$ & $C_{U}^{i}$ & $C_{M}^{i}$ & $O_{L}^{i}$ & $O_{L}^{i}$ & $O_{M}^{i}$ & \\
\hline CS1 & 4 & 7 & 5.40 & 7 & 10 & 8.93 & 7.00 \\
\hline CS2 & 4 & 8 & 5.63 & 7 & 10 & 8.47 & 7.38 \\
\hline CS3 & 4 & 8 & 6.03 & 7 & 10 & 8.63 & 7.45 \\
\hline CS4 & 4 & 8 & 5.60 & 6 & 10 & 8.17 & 6.95 \\
\hline CS5 & 4 & 7 & 5.00 & 6 & 9 & 7.93 & 6.49 \\
\hline CS6 & 4 & 7 & 5.53 & 6 & 10 & 8.60 & 6.64 \\
\hline IB1 & 4 & 8 & 5.67 & 7 & 10 & 8.60 & 7.41 \\
\hline IB2 & 4 & 7 & 5.60 & 7 & 10 & 8.40 & 7.00 \\
\hline IB3 & 4 & 8 & 5.80 & 7 & 10 & 8.90 & 7.46 \\
\hline IB4 & 4 & 8 & 5.70 & 6 & 10 & 8.60 & 7.06 \\
\hline IB5 & 4 & 8 & 5.77 & 7 & 10 & 8.57 & 7.41 \\
\hline BC1 & 4 & 8 & 5.90 & 6 & 10 & 8.40 & 7.07 \\
\hline BC2 & 4 & 7 & 5.47 & 6 & 9 & 7.67 & 6.52 \\
\hline BC3 & 4 & 8 & 5.77 & 6 & 10 & 8.33 & 7.02 \\
\hline BC4 & 4 & 8 & 5.67 & 6 & 10 & 8.63 & 7.06 \\
\hline BC5 & 4 & 7 & 5.43 & 6 & 9 & 7.87 & 6.54 \\
\hline BC6 & 4 & 8 & 5.57 & 6 & 10 & 7.83 & 6.86 \\
\hline BC7 & 3 & 7 & 5.27 & 6 & 9 & 8.10 & 6.55 \\
\hline
\end{tabular}

\subsection{Introduction of AHP framework}

In the previous section, the first stage was to determine the key factors by using FDM. In the second stage, the AHP expert questionnaire investigation was conducted. At this stage, experts and researchers were still the objects of investigation. Besides establishing the hierarchal framework for the selection of a residential environment in Taiwan, it was also essential to understand the correla- tion between each influential factor to acquire the relative weighing between factors of different levels as well as the overall weighting; both were used to plan subsequent supporting measures. Based on the investigation results, the order and weighting distribution of factors were determined to reduce the hypothesis value, allowing the decision-making to be more objective and appropriate in matching the actual demand. The various relevant elements, definitions and criteria are thus explained so as to help readers better understand the goals of the study (Please refer to Table A1).

\subsection{Sample structure analysis}

According to Hsueh the AHP requires at least a year to yield results of a necessary level of consistency (Hsueh, 2012). This study took more than a year to complete, and had a very rigorous approach during the research process. As such, the results and conclusions from our questionnaire meet a certain standard. The questionnaire data passed the consistency test (i.e., $\mathrm{CR} \leq 0.1$ ). The data from which were used to calculate the relative weighting values of the three assessment dimensions (Table 3).

\subsection{Selection of utility function}

Based on the questionnaire completed by professionals and scholars, the evaluative elements were determined. In addition to participants who responded and conformed to the traditional binary of "absolutely important" or "absolutely unimportant" (0 points or 100 points respectively), other responses were processed using the utility function. Because of a large variation between the assessment content and the informational attributes associated with the three criteria, four methodologies were used to solve the problem. The results were objectively quantified using the utility function (Table 4 ). The community service facilities

Table 3. Relative weights of major criteria and minor criteria

\begin{tabular}{|c|c|c|c|c|c|}
\hline Criteria & Level (1) $W_{i}$ & Sub-criteria & Level (2) $W_{i}$ & Overall $W_{i}$ & $\begin{array}{l}\text { Overall } \\
\text { sequence }\end{array}$ \\
\hline \multirow{4}{*}{$\begin{array}{l}\text { Community service } \\
\text { facilities }\end{array}$} & \multirow[t]{4}{*}{38.72} & Cultural education facility (CS1) & 28.81 & 9.60 & 5 \\
\hline & & Sport and leisure (CS2) & 31.12 & 10.37 & 2 \\
\hline & & Living convenience facility (CS3) & 30.95 & 10.32 & 3 \\
\hline & & Community welfare (CS4) & 9.12 & 3.04 & 13 \\
\hline \multirow{5}{*}{$\begin{array}{l}\text { Innovation green } \\
\text { building design }\end{array}$} & \multirow[t]{5}{*}{33.04} & Safety design (IB1) & 36.27 & 12.09 & 1 \\
\hline & & Health design (IB2) & 23.59 & 7.86 & 8 \\
\hline & & Convenience design (IB3) & 16.18 & 5.39 & 10 \\
\hline & & Comfort design (IB4) & 13.06 & 4.35 & 11 \\
\hline & & Sustainability design (IB5) & 10.90 & 3.63 & 12 \\
\hline \multirow[t]{4}{*}{ Building construction } & \multirow[t]{4}{*}{28.24} & Foundation condition and terrain issue (BC1) & 20.74 & 6.91 & 9 \\
\hline & & Green construction materials (BC3) & 24.26 & 8.09 & 7 \\
\hline & & Innovation technology (BC4) & 29.62 & 9.87 & 4 \\
\hline & & Schedule delay (BC6) & 25.38 & 8.46 & 6 \\
\hline \multicolumn{3}{|l|}{$W_{i}=W_{i} \cdot 100 \%$} & 300 & 100 & \\
\hline
\end{tabular}


aspect $(\mathrm{F}(\mathrm{X} 1)=\mathrm{CS} 1-\mathrm{CS} 6)$ has a fuzzy range of $300 \mathrm{~m} \sim$ $1,200 \mathrm{~m}$. A study has indicated that the best distance for the public to walk to various public facilities is within 500 $\mathrm{m}$. If the distance exceeds $1,200 \mathrm{~m}$, it will be deemed rather inconvenience for the people. Meanwhile, as the walking distance will also affect the utility rate of public facilities, so the distance value of $300 \mathrm{~m}$ from community service facilities is set as 100. The innovation green building design aspect $(\mathrm{F}(\mathrm{X} 2)=\mathrm{IB} 1-\mathrm{IB} 5)$ has a fuzzy range of $0 \sim 100$. The Safety design (IB1) and health design (IB2) aspects are set as 90 due to their great relationships to professional considerations, building age and maintenance. The convenience design (IB3) and comfort design (IB4) aspects are set as 80 to meet the user requirements on space convenience and comfort. The sustainability design (IB5) aspect is set as 70 based on "energy efficiency" and "energy management". The building construction aspect $(\mathrm{F}(\mathrm{X} 3)=$ $\mathrm{BC} 1-\mathrm{BC} 6)$ has a fuzzy range of $0 \sim 100$. The foundation conditions and terrain issue $(\mathrm{BC} 1)$ are set as 80 due to ongoing improvement in building construction technologies, and the fact that for a construction base in Taiwan, the time needed from land development to completion of housing is at least $3 \sim 5$ years. The green construction materials (BC3) is set as 70; innovation technology (BC4) is set as 80; Schedule delay (BC6) is set as 100. What follows are the utility values predicted using AHP and utility theory. The calculated results show that the worst case will produce an expected utility value (EUV) of -133.93 and the best case will produce an EUV of 89.18.

\section{Case study}

Based on a survey of related articles and site visits, we have chosen locations with optimal living environments. In order to verify the feasibility of this model, we will use the Taipei City Government's "Social Housing Project" as an example application. Of the eleven "Social Housing Projects" established by the Taipei City Government, we selected two projects as our subjects for the empirical case study. Due to the differences in locations, real estate prices and completion times of the other nine social housing units, we selected "Xinglong Social Housing Project" and "Jingwen Social Housing Project", units which are located in the same region and have fewer differences as the examples. We selected 50 residents each from Xinglong Social Housing and Jingwen Social Housing to participate in our survey with 100 residents. They are residents who are all very active to involve in their community development and improvement. All questions were answered and returned. We have $100 \%$ of response rate on this survey.

The first study project, the Xinglong Social Housing Project, was the only one out of the eleven that had the smallest margins between the completion of the construction and the rental and occupancy dates. In addition,

Table 4. For the quantitative values generated using the utility function

\begin{tabular}{|c|c|c|c|c|c|c|c|}
\hline Criterion & $y_{L}$ & $y_{H}$ & $y_{m i}$ & $y_{m a}$ & A & B & $\begin{array}{l}\text { Utility function } \\
u_{i}\left(y_{i}\right)=A_{y i}+B\end{array}$ \\
\hline CS1 & 0 & 100 & 40 & 80 & 0.025 & -1.00 & $u_{i}\left(y_{i}\right)=0.025 y i-1$ \\
\hline CS2 & 0 & 100 & 40 & 80 & 0.025 & -1.00 & $u_{i}\left(y_{i}\right)=0.025 y i-1$ \\
\hline CS3 & 0 & 100 & 50 & 80 & 0.033 & -1.67 & $u_{i}\left(y_{i}\right)=0.033 y i-1.67$ \\
\hline CS4 & 0 & 100 & 40 & 80 & 0.025 & -1.00 & $u_{i}\left(y_{i}\right)=0.025 y i-1$ \\
\hline IB1 & 20 & 90 & 50 & 70 & 0.050 & -2.50 & $u_{i}\left(y_{i}\right)=0.050 y i-2.5$ \\
\hline IB2 & 20 & 90 & 50 & 70 & 0.050 & -2.50 & $u_{i}\left(y_{i}\right)=0.050 y i-2.5$ \\
\hline IB3 & 10 & 80 & 40 & 80 & 0.025 & -1.00 & $u_{i}\left(y_{i}\right)=0.025 y i-1$ \\
\hline IB4 & 20 & 80 & 50 & 80 & 0.033 & -1.67 & $u_{i}\left(y_{i}\right)=0.033 y i-1.67$ \\
\hline IB5 & 10 & 70 & 40 & 60 & 0.050 & -2.00 & $u_{i}\left(y_{i}\right)=0.05 y i-2$ \\
\hline $\mathrm{BC} 1$ & 0 & 80 & 30 & 80 & 0.020 & -0.60 & $u_{i}\left(y_{i}\right)=0.20 y i-0.6$ \\
\hline BC3 & 0 & 70 & 30 & 60 & 0.033 & -1.00 & $u_{i}\left(y_{i}\right)=0.033 y i-1$ \\
\hline $\mathrm{BC} 4$ & 0 & 80 & 40 & 70 & 0.033 & -1.33 & $u_{i}\left(y_{i}\right)=0.033 y i-1.33$ \\
\hline BC6 & 0 & 100 & 50 & 80 & 0.033 & -1.67 & $u_{i}\left(y_{i}\right)=0.033 y i-1.67$ \\
\hline
\end{tabular}


every unit in the Xinglong Social Housing Project was rented for public residential use. The name of the second project used for Case Study B is Jingwen Social Housing Project, which is located in Taipei's Wenshan District. The residents of the Case Study B project occupied the housing based on a "mixed configuration" (Department of Urban Development, 2014, 2017). Please see the list below for a more detailed explanation:

- The housing project from Case Study A was previously a part of Taipei's Ankang Pingjia residential neighborhood. Adjacent to this residential neighborhood was municipal property, including an under frequented market-called the Ankang Market-and a parking lot. The community was re-planned and reorganized for a public housing project. The goal was to improve the quality of life and visual appearance of the neighborhood. The project was completed by
Taipei City Government's Department of Urban Development Council.

- Case Study B is the first instance in which the Taipei City Government converted a residential complex into public housing. In March of 2012 construction was completed. In April of 2014 the public housing was opened for people to move in. There are a total of 39 units in the housing complex.

- When comparing the two case studies, Case Study A is a better model (See Table 6 and Figure 2). The model will be able to adjust the quantized utility function values according to our respondents' attitude toward risk. When adjusting these values, it is necessary to also update Tables 4 to 6 . A change in the decision elements will affect the relationship between different EUVs. Thus, decisions can be made to maximize utility.

Table 5. Expected utility value for criteria

\begin{tabular}{|c|c|c|c|c|c|}
\hline \multirow{2}{*}{ Criterion } & \multirow{2}{*}{$W_{i} \cdot 100 \%$} & & \multicolumn{2}{|c|}{$u_{r i} \cdot\left(W_{i}\right)$} \\
\cline { 3 - 6 } & & Worst & Optimal & Worst & Optimal \\
\hline CS1 & 9.60 & -1.00 & 1.00 & -9.60 & 9.60 \\
\hline CS2 & 10.37 & -1.00 & 1.00 & -10.37 & 10.37 \\
\hline CS3 & 10.32 & -1.67 & 1.00 & -17.20 & 3.32 \\
\hline CS4 & 3.04 & -1.00 & 1.00 & -3.04 & 10.88 \\
\hline IB1 & 12.09 & -2.50 & 0.90 & -27.20 & 7.08 \\
\hline IB2 & 7.86 & -2.50 & 0.90 & -17.69 & 4.31 \\
\hline IB3 & 5.39 & -1.00 & 0.80 & -4.31 & 3.48 \\
\hline IB4 & 4.35 & -1.67 & 0.80 & -5.81 & 2.54 \\
\hline IB5 & 3.63 & -2.00 & 0.70 & -5.09 & 5.53 \\
\hline BC1 & 6.91 & -0.60 & 0.80 & -3.32 & 5.66 \\
\hline BC3 & 8.09 & -1.00 & 0.70 & -5.66 & 7.90 \\
\hline BC4 & 9.87 & -1.33 & 0.80 & -10.53 & 8.46 \\
\hline BC6 & 8.46 & -1.67 & 1.00 & -14.10 & \\
\hline EUV & & & & -133.93 & \\
\hline
\end{tabular}

Table 6. For assessments of the overall living environment values

\begin{tabular}{|c|c|c|c|c|c|}
\hline $\begin{array}{l}\text { Criteria } \\
\text { criterion }\end{array}$ & $W_{i}$ & Case study A & $u_{r i} \cdot\left(W_{i}\right)$ & Case study B & $u_{r i} \cdot\left(W_{i}\right)$ \\
\hline CS1 & 9.60 & 80 & 7.68 & 75 & 7.20 \\
\hline CS2 & 10.37 & 80 & 8.30 & 75 & 7.78 \\
\hline CS3 & 10.32 & 80 & 8.25 & 80 & 8.25 \\
\hline CS4 & 3.04 & 80 & 2.43 & 80 & 2.43 \\
\hline IB1 & 12.09 & 80 & 9.67 & 65 & 7.86 \\
\hline IB2 & 7.86 & 80 & 6.29 & 65 & 5.11 \\
\hline IB3 & 5.39 & 80 & 4.31 & 80 & 4.31 \\
\hline IB4 & 4.35 & 80 & 3.48 & 80 & 3.48 \\
\hline IB5 & 3.63 & 65 & 2.36 & 50 & 1.82 \\
\hline $\mathrm{BC} 1$ & 6.91 & 75 & 5.19 & 75 & 5.19 \\
\hline BC3 & 8.09 & 65 & 5.26 & 50 & 4.04 \\
\hline $\mathrm{BC} 4$ & 9.87 & 75 & 7.41 & 70 & 6.91 \\
\hline BC6 & 8.46 & 100 & 8.46 & 100 & 8.46 \\
\hline EUV & & & 79.09 & & 72.85 \\
\hline
\end{tabular}




\section{Results and discussion}

\subsection{Research findings}

In this section, we'll explain the factors in two parts as follows:

\section{Results of AHP analysis}

It is noted from Table 3 in the three assessment aspects, "community service facility" carries relatively more weight than the other two factors. With regard to the degree of importance in the selection of residential location, "innovative green building design" is the foundation among all factors and is also a relatively important assessment criterion, followed by "building construction". In the study on the real estate assessment model, Ozsoy, Altas, Ok, and Pulat (1996) proposed that the comfort of the external environment and the distance between public facilities deserve more attention in the architectural planning and design. As a result, green building design has been adopted by many developing and developed countries for the sake of solving their urban environmental issues. The research finding shows that regional environmental conditions and architectural design are important factors that attract consumers (Altaş \& Ozsoy, 1998; Cho \& Lee, 2011; Ozsoy et al., 1996). which is in line with the findings of this study. The Top 3 secondary improvement aspects in terms of importance are "community wellbeing", "sustainable design" and "comfort design". In terms of community wellbeing, since the situation of declining birth rate in Taiwan is more severe than other countries, the elderly care system and community babysitting system need to be enhanced.
Sustainable design and comfort design are required in the interior design. Accordingly, in constructing a new home, natural ventilation design shall be adopted. Large windows should be used to introduce natural sunlight and air into the building, providing sufficient indoor lighting and expanding the visual field. In terms of facilities, environmental friendly, recyclable materials and energysaving equipment shall be used. Lastly, in order to create a nuclear-free Taiwan, architectural design shall be used to facilitate the transformation. In addition, the implementation of sustainable energy policies and the promotion of various energy-saving and carbon reduction measures supplemented with environmental education shall also be conducted to achieve the goal of energy conservation and avoid energy waste.

\section{Utility decision model analysis}

The decision model we used to choose residential environments is based on scientific calculations and empirical case studies. This model can help decision makers evaluate utility values and profitability, so as to select the most suitable environment. The model has the following applications:

- As a reference for the public sector when promoting social housing and the development of relevant policies.

- As a self-assessment tool for people looking to buy or rent housing.

- As a means for private building developers to objectively evaluate risks when making decisions related to land development.

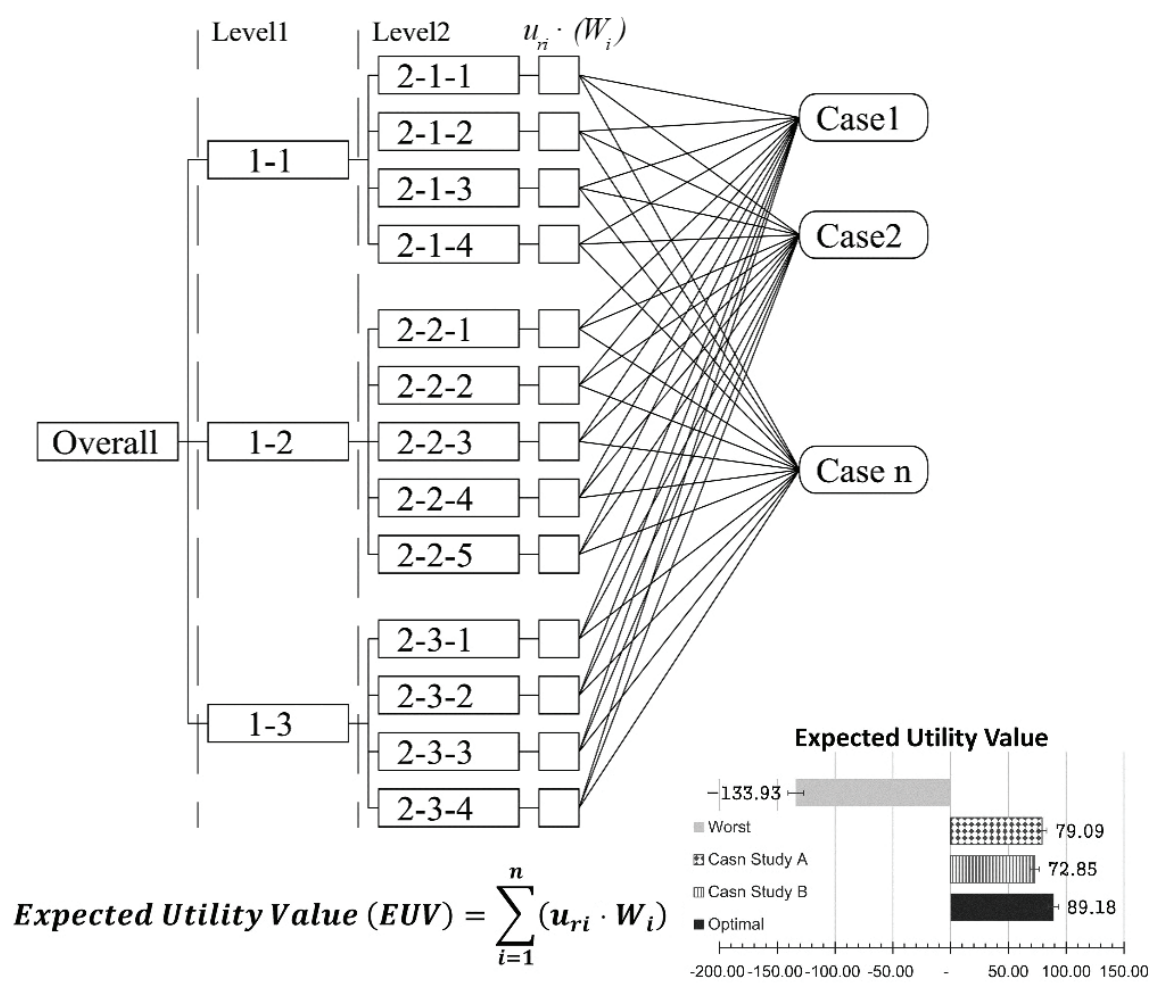

Figure 2. Schematic of the assessment results for case study A-B 
Experts agree that inappropriate land development decisions are a cause of wasted land resources and that such bad decisions can negatively impact urban landscapes and the environment. Therefore, it is recommended when making plans related to future residential environment or land development projects, one should prioritize community input, sustainability, and low-carbon emissions.

\subsection{Discussion}

In recent years, many scholars have conducted studies on the selection of real estate location, which shows the importance of such research. Yet few studies regarding the social housing in Taiwan have been conducted. Social housing development started relatively late in Asia compared to Europe which has a history of more than a century. In Asia, while Hong Kong and Singapore already have sound social housing development, Taiwan was the last to begin such planning. According to the survey, Taiwan started to construct social housing under the concern and demand of civil organizations and various social groups in 2010 when high housing prices and residential issues were at a critical stage. After a century of development, Taipei City-a city with limited land resources-now emphasizes on sustainability, environmentalism and low-carbon emissions as important aspects in its urban development policies. We can see that the government currently requires developers to research and implement environmentally friendly plans and community input mechanisms in many building development cases. At the same time, developers must cater to the needs of residents of all ages, and integrate common design principles in addition to green ones during the planning and design stages in order to increase the comfort and safety of residents. While pursuing economic development, it is important to make decisions that are humane and promote environmental sustainability. Below is a further explanation:

- The public has shown support for plans to update residential buildings. The construction and renovation plans can be done in a way that promotes environmental protection.

- Our experimental results provide a practical and unique model for deciding on a residential environment.

- Our model has a high degree of objective value and reference value, and it is beneficial for future updates and maintenance.

- Taiwan's real estate is governed by market forces. As such, it is necessary to create comfortable and affordable housing.

\section{Conclusions}

As it is difficult to access private sector records, our case studies focused on the social housing projects of the Taipei City Government. If it is possible to gain future access to private sector records, more accurate and objective results may be obtained. We suggest that the government should cooperate with the private sector to locate land for social housing projects. This will be a comprehensive solution to ensure that people can access housing. Governments should also strengthen community welfare and neighborhood development and incorporate the required social resources to bring social welfare services into the community (such childcare, elder care, and community welfare service centers). The elder care system should also be improved because it will be the key issue in the development of Taiwan's future society. It can also serve as a useful reference to the general public in assessing their living environment. Follow-up research could extend the research time period, or approach the study from the timing data's horizontal and vertical perspectives, for analysis and comparison, in order to deepen research on social housing projects in Taiwan.

\section{Acknowledgements}

The authors greatly thank two anonymous referees for giving their constructive comments on improving the quality of this paper.

\section{References}

Abrahamsen, E. B., \& Asche, F. (2011). On how access to an insurance market affects investments in safety measures, based on the expected utility theory. Reliability Engineering \& System Safety, 96(3), 361-364.

https://doi.org/10.1016/j.ress.2010.10.004

Afacan, Y. (2011). Teaching universal design: an empirical research in interior architecture. Procedia-Social and Behavioral Sciences, 15, 3185-3192.

https://doi.org/10.1016/j.sbspro.2011.04.269

Ali, H. H., \& Al Nsairat, S. F. (2009). Developing a green building assessment tool for developing countries - case of Jordan. Building and Environment, 44(5), 1053-1064. https://doi.org/10.1016/j.buildenv.2008.07.015

Altaş, N. E., \& Özsoy, A. (1998). Spatial adaptability and flexibility as parameters of user satisfaction for quality housing. Building and Environment, 33(5), 315-323. https://doi.org/10.1016/S0360-1323(97)00050-4

Altomonte, S., Schiavon, S., Kent, M. G., \& Brager, G. (2019). Indoor environmental quality and occupant satisfaction in greencertified buildings. Building Research \& Information, 47(3), 255-274. https://doi.org/10.1080/09613218.2018.1383715

Bathrellos, G. D., Skilodimou, H. D., Chousianitis, K., Youssef, A. M., \& Pradhan, B. (2017). Suitability estimation for urban development using multi-hazard assessment map. Science of the Total Environment, 575, 119-134. https://doi.org/10.1016/j.scitotenv.2016.10.025

Borade, A. B., Kannan, G., \& Bansod, S. V. (2013). Analytical hierarchy process-based framework for VMI adoption. International Journal of Production Research, 51(4), 963-978. https://doi.org/10.1080/00207543.2011.650795

Chen, Y. L., Cheng, A. C., Hsueh, S. L., \& Qu, D. (2017). DAHP expected utility based evaluation model for management performance on interior environmental decoration - an example in Taiwan. Eurasia Journal of Mathematics, Science and Technology Education, 13(12), 8257-8265.

https://doi.org/10.12973/ejmste/78635 
Chen, Y. Q., Liu, J. Y., Li, B. G., \& Lin, B. S. (2011). Project delivery system selection of construction projects in China. Expert Systems with Applications, 38(5), 5456-5462. https://doi.org/10.1016/j.eswa.2010.10.008

Chiang, C. M., \& Lai, C. M. (2002). A study on the comprehensive indicator of indoor environment assessment for occupants' health in Taiwan. Building and Environment, 37(4), 387-392. https://doi.org/10.1016/S0360-1323(01)00034-8

Chiang, T. Y., Perng, Y. H., \& Liou, L. E. (2017). Impact and adaptation strategies in response to climate change on Taiwan's water resources. Applied Mechanics \& Materials, 858, 335-341. https://doi.org/10.4028/www.scientific.net/AMM.858.335

Cho, S. H., \& Lee, T. K. (2011). A study on building sustainable communities in high-rise and high-density apartments - focused on living program. Building and Environment, 46(7), 1428-1435. https://doi.org/10.1016/j.buildenv.2011.01.004

Demirbilek, O., \& Demirkan, H. (2004). Universal product design involving elderly users: a participatory design model. Applied Ergonomics, 35(4), 361-370.

https://doi.org/10.1016/j.apergo.2004.03.003

Department of Urban Development. (2014). Division of Housing Engineering, Department of Urban Development, Taipei City Government, Taipei. Retrieved from http://www.udd.gov.taipei/pages $/$ detail.aspx ?Node $=44 \&$ Page $=7130$

Department of Urban Development. (2017). Division of Housing Engineering, Department of Urban Development, Taipei City Government, Taipei. Retrieved from http://www.udd.gov.taipei/pages $/$ detail.aspx? Node $=44 \&$ Page $=7804$

Dozzi, S. P., AbouRizk, S. M., \& Schroeder, S. L. (1996). Utilitytheory model for bid markup decisions. Journal of Construction Engineering and Management, 122(2), 119-124. https://doi.org/10.1061/(ASCE)0733-9364(1996)122:2(119)

GhaffarianHoseini, A., Dahlan, N. D., Berardi, U., GhaffarianHoseini, A., Makaremi, N., \& GhaffarianHoseini, M. (2013). Sustainable energy performances of green buildings: a review of current theories, implementations and challenges. Renewable and Sustainable Energy Reviews, 25, 1-17. https://doi.org/10.1016/j.rser.2013.01.010

Han, S. H., Kim, D. Y., Kim, H., \& Jang, W. S. (2008). A webbased integrated system for international project risk management. Automation in Construction, 17(3), 342-356. https://doi.org/10.1016/j.autcon.2007.05.012

Hassan, A. M., \& Lee, H. (2015). Toward the sustainable development of urban areas: an overview of global trends in trials and policies. Land Use Policy, 48, 199-212.

https://doi.org/10.1016/j.landusepol.2015.04.029

Hsueh, S. L. (2012). A fuzzy utility-based multi-criteria model for evaluating households' energy conservation performance: a Taiwanese case study. Energies, 5(8), 2818-2834. https://doi.org/10.3390/en5082818

Hsueh, S. L., \& Yan, M. R. (2013). A multimethodology contractor assessment model for facilitating green innovation: the view of energy and environmental protection. The Scientific World Journal, 2013. https://doi.org/10.1155/2013/624340

Hwang, B. G., \& Ng, W. J. (2013). Project management knowledge and skills for green construction: overcoming challenges. International Journal of Project Management, 31(2), 272284. https://doi.org/10.1016/j.ijproman.2012.05.004

Ishikawa, A., Amagasa, M., Shiga, T., Tomizawa, G., Tatsuta, R., \& Mieno, H. (1993). The max-min Delphi method and fuzzy Delphi method via fuzzy integration. Fuzzy Sets and Systems, 55(3), 241-253. https://doi.org/10.1016/0165-0114(93)90251-C

Kadir, S. A., \& Jamaludin, M. (2013). Universal design as a significant component for sustainable life and social develop- ment. Procedia-Social and Behavioral Sciences, 85, 179-190. https://doi.org/10.1016/j.sbspro.2013.08.349

Kuo, Y. F., \& Chen, P. C. (2008). Constructing performance appraisal indicators for mobility of the service industries using fuzzy Delphi method. Expert Systems with Applications, 35(4), 1930-1939. https://doi.org/10.1016/j.eswa.2007.08.068

Lam, P. T. I., Chan, E. H. W., Poon, C. S., Chau, C. K., \& Chun, K. P. (2010). Factors affecting the implementation of green specifications in construction. Journal of Environmental Management, 91(3), 654-661.

https://doi.org/10.1016/j.jenvman.2009.09.029

Larsen, J. K., Shen, G. Q., Lindhard, S. M., \& Brunoe, T. D. (2016). Factors affecting schedule delay, cost overrun, and quality level in public construction projects. Journal of Management in Engineering, 32(1), 04015032.

https://doi.org/10.1061/(ASCE)ME.1943-5479.0000391

Leaman, A., \& Bordass, B. (2007). Are users more tolerant of "green" buildings? Building Research \& Information, 35(6), 662-673. https://doi.org/10.1080/09613210701529518

Lee, S., \& Seo, K. K. (2016). A hybrid multi-criteria decisionmaking model for a cloud service selection problem using BSC, fuzzy Delphi method and fuzzy AHP. Wireless Personal Communications, 86(1), 57-75.

https://doi.org/10.1007/s11277-015-2976-Z

Liu, K. S., Hsueh, S. L., Wu, W. C., \& Chen, Y. L. (2012). A DFuzzy-DAHP decision-making model for evaluating energy-saving design strategies for residential buildings. Energies, 5(11), 4462-4480. https://doi.org/10.3390/en5114462

Luce, R. D. (1956). Semiorders and a theory of utility discrimination. Econometrica, Journal of the Econometric Society, 4, 178-191. https://doi.org/10.2307/1905751

Ministry of the Interior, Taiwan. (2015). EEWH-NC (Evaluation Manual for Green Building in Taiwan). Architecture and Building Research Institute.

Murray, D., \& Howat, G. (2002). The relationships among service quality, value, satisfaction, and future intentions of customers at an Australian sports and leisure centre. Sport Management Review, 5(1), 25-43. https://doi.org/10.1016/S1441-3523(02)70060-0

Murray, T. J., Pipino, L. L., \& Van Gigch, J. P. (1985). A pilot study of fuzzy set modification of Delphi. Human Systems Management, 5(1), 76-80.

Ozsoy, A., Altas, N. E., Ok, V., \& Pulat, G. (1996). Quality assessment model for housing: a case study on outdoor spaces in Istanbul. Habitat International, 20(2), 163-173. https://doi.org/10.1016/0197-3975(95)00045-3

Paul, W. L., \& Taylor, P. A. (2008). A comparison of occupant comfort and satisfaction between a green building and a conventional building. Building and Environment, 43(11), 18581870. https://doi.org/10.1016/j.buildenv.2007.11.006

Pohekar, S. D., \& Ramachandran, M. (2004). Application of multi-criteria decision making to sustainable energy planning - A review. Renewable and Sustainable Energy Reviews, 8(4), 365381. https://doi.org/10.1016/j.rser.2003.12.007

Qi, G. Y., Shen, L. Y., Zeng, S. X., \& Jorge, O. J. (2010). The drivers for contractors' green innovation: an industry perspective. Journal of Cleaner Production, 18(14), 1358-1365. https://doi.org/10.1016/j.jclepro.2010.04.017

Rehman, O. U., \& Ryan, M. J. (2018). A framework for design for sustainable future-proofing. Journal of Cleaner Production, 170, 715-726. https://doi.org/10.1016/j.jclepro.2017.09.177

Retzlaff, R. C. (2008). Green building assessment systems: a framework and comparison for planners. Journal of the American Planning Association, 74(4), 505-519. https://doi.org/10.1080/01944360802380290 
Rubin, H. J., \& Rubin, I. S. (2011). Qualitative interviewing: the art of hearing data (3rd ed.). Thousand Oaks, CA: Sage.

Saaty, T. L. (1990). How to make a decision: the analytic hierarchy process. European Journal of Operation Research, 48(1), 9-26. https://doi.org/10.1016/0377-2217(90)90057-I

Santoso, D. S., \& Soeng, S. (2016). Analyzing delays of road construction projects in Cambodia: causes and effects. Journal of Management in Engineering, 32(6), 05016020. https://doi.org/10.1061/(ASCE)ME.1943-5479.0000467

Weiss, R. S. (1994). Learning from strangers: the art and method of qualitative interview studies. New York, NY: The Free Press.

World Health Organization (WHO). (1961). Expert Committee on the Public Health Aspects of Housing. Retrieved from http://apps. who.int/iris/bitstream/10665/40497/1/WHO_TRS_225.pdf

Yang, R. J., Zou, P. X. W., \& Wang, J. (2016). Modelling stakeholder-associated risk networks in green building projects.
International Journal of Project Management, 34(1), 66-81. https://doi.org/10.1016/j.ijproman.2015.09.010

Zadeh, L. A. (1965). Fuzzy sets. Information and Control, 8(3), 338-353. https://doi.org/10.1016/S0019-9958(65)90241-X

Zeeman, H., Wright, C. J., \& Hellyer, T. (2016). Developing design guidelines for inclusive housing: a multi-stakeholder approach using a Delphi method. Journal of Housing and the Built Environment, 4(31), 761-772.

https://doi.org/10.1007/s10901-016-9499-0

Zhang, X., Platten, A., \& Shen, L. (2011). Green property development practice in China: costs and barriers. Building and Environment, 46(11), 2153-2160.

https://doi.org/10.1016/j.buildenv.2011.04.031

Zimmermann, H. J. (2010). Fuzzy set theory. Wiley Interdisciplinary Reviews: Computational Statistics, 2(3), 317-332.

https://doi.org/10.1002/wics.82

\section{Appendix}

Table A1. Provides an assessment of the relevant elements, definitions and criteria

\begin{tabular}{|c|c|c|}
\hline Element & Factor & Criterion-referenced assessments \\
\hline \multirow[t]{4}{*}{$\begin{array}{c}\text { Community } \\
\text { service facilities }\end{array}$} & $\begin{array}{c}\text { Cultural } \\
\text { education facility }\end{array}$ & $\begin{array}{l}\text { Refers to the relative distance between the survey target and a neighboring communal facility } \\
\text { (e.g. public elementary school, public middle school, or library) }\end{array}$ \\
\hline & Sport and leisure & $\begin{array}{l}\text { Refers to the relative distance between the survey target and a neighboring communal facility } \\
\text { (e.g. park, green land, community center) }\end{array}$ \\
\hline & $\begin{array}{l}\text { Living } \\
\text { convenience } \\
\text { facility }\end{array}$ & $\begin{array}{l}\text { Refers to the relative distance between the survey target and a neighboring communal facility } \\
\text { (e.g. traffic, medical, shopping) }\end{array}$ \\
\hline & $\begin{array}{l}\text { Community } \\
\text { welfare }\end{array}$ & $\begin{array}{l}\text { Refers to the relative distance between the survey target and a neighboring communal facility } \\
\text { (e.g. care for the elderly, community babysitting, kindergarten) }\end{array}$ \\
\hline \multirow[t]{5}{*}{$\begin{array}{c}\text { Innovation } \\
\text { green building } \\
\text { design }\end{array}$} & Safety design & $\begin{array}{l}\text { To strive to enhance residents' quality of life and encourage "human-oriented" space planning } \\
\text { design. Human-oriented space planning design focuses on the preservation of property and } \\
\text { life. It is a way to create higher-quality and safer living spaces for clients }\end{array}$ \\
\hline & Health design & $\begin{array}{l}\text { The criteria for evaluation can be divided into the following four categories: visual appearance, } \\
\text { air quality, water quality, and health care systems } \\
\text { Visual appearance: an index determined by the installed lighting features and the effective } \\
\text { illumination of the inside of the structure } \\
\text { Air quality: measures taken to filter the air and control the air quality within the structure } \\
\text { Water quality: measures taken to ensure the structure's water supply and the quality of the water } \\
\text { Health Care System: providing medical services essential to spaces-both public and private- } \\
\text { that are dedicated to medical information services and medical services }\end{array}$ \\
\hline & $\begin{array}{l}\text { Convenience } \\
\text { design }\end{array}$ & Refers to creating a high-quality living space by designing convenient friendly services \\
\hline & Comfort design & $\begin{array}{l}\text { Refers to the use of common design approaches to provide clients with a sense of mental and } \\
\text { physical leisure }\end{array}$ \\
\hline & $\begin{array}{l}\text { Sustainability } \\
\text { design }\end{array}$ & $\begin{array}{l}\text { Evaluations based on efficient use and management of energy, i.e. is the building equipped } \\
\text { with high efficiency, energy-saving air conditioning, lighting, and power equipment? Is it } \\
\text { equipped with equipment for monitoring and managing energy usage? }\end{array}$ \\
\hline \multirow[t]{4}{*}{$\begin{array}{l}\text { Building } \\
\text { construction }\end{array}$} & $\begin{array}{l}\text { Foundation } \\
\text { condition and } \\
\text { terrain issue }\end{array}$ & $\begin{array}{l}\text { Refers to the assessment of the infrastructure (i.e. its orderliness, dimensions, road conditions, } \\
\text { geological conditions, etc.) }\end{array}$ \\
\hline & $\begin{array}{l}\text { Green } \\
\text { construction } \\
\text { materials }\end{array}$ & $\begin{array}{l}\text { Refers to the materials (i.e. new, low-carbon, low-energy, environmental or recyclable } \\
\text { materials) used to build the structure }\end{array}$ \\
\hline & $\begin{array}{l}\text { Innovation } \\
\text { technology }\end{array}$ & $\begin{array}{l}\text { Using the construction of new buildings to promote green design, smart and high-tech } \\
\text { technologies and materials, and related products }\end{array}$ \\
\hline & Schedule delay & Project progress (i.e. behind schedule, normal, ahead of schedule) \\
\hline
\end{tabular}

